\title{
Growth Response of Improved Breeds of Native Chicken to Diets Differed in Energy and Protein Content
}

\author{
Hidayat C, Iskandar S, Sartika T, Wardhani T \\ Indonesian Research Institute for Animal Production, \\ Jl. Veteran III, Banjarwaru Ciawi PO Box 221 Bogor 16720 \\ E-mail: hidayat_c2p@yahoo.com \\ (received 11-07-2016; revised 07-09-2016; accepted 13-09-2016)
}

\begin{abstract}
ABSTRAK
Hidayat C, Iskandar S, Sartika T, Wardhani T. 2016. Respon pertumbuhan galur ayam lokal terseleksi terhadap ransum dengan kadar energi metabolis dan protein berbeda. JITV 21(3): 174-181. DOI: http://dx.doi.org/10.14334/jitv.v21i3.1397

Penelitian ini bertujuan untuk mengetahui respon pertumbuhan galur ayam lokal hasil seleksi terhadap ransum dengan kadar energi metabolis dan protein ransum berbeda.. Tiga kelompok anak ayam hasil perkawinan galur ayam lokal terseleksi, yaitu

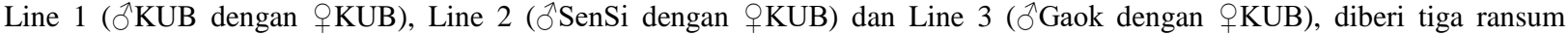
perlakuan berbeda, yang terdiri dari ransum Diet 1 (2800 kkal ME/ kg dengan 17,81\% protein kasar), Diet 2, (2950 kkal ME/ kg dengan 18,61\% protein kasar) dan Diet 3 (3100 kkal ME/ kg dengan 19,25\% protein kasar). Percobaan ini menggunakan rancangan percobaan faktorial $3 \times 3$. Setiap kombinasi perlakuan diulang sebanyak 7 kali dengan jumlah anak ayam umur sehari (DOC) sebanyak 5 ekor/ulangan, yang dipelihara sampai dengan umur 10 minggu. Hasil penelitian menunjukkan bahwa galur Line $2(\widehat{S}$ SenSi x 9 KUB) menunjukkan bobot hidup umur 10 minggu yang lebih tinggi $(\mathrm{P}<0,05)$, feed conversion ratio (FCR) yang rendah dan European Production Efficiency Factor (EPEF) yang tinggi, dibandingkan dengan kedua galur lainnya. Ransum yang optimum untuk galur Line 2 adalah ransum Diet 2, maka diambil kesimpulan bahwai galur ayam hasil perkawinan $\widehat{\partial} \mathrm{SenSi}$ dengan $\$$ KUB berpotensi untuk dimanfaatkan sebagai ayam lokal tipe pedaging komersial di Indonesia dengan menggunakan ransum optimum yang mempunyai kadar energi $2950 \mathrm{kcal} \mathrm{ME} / \mathrm{kg}$ dengan 18,61\% protein kasar.
\end{abstract}

Kata Kunci: Ayam KUB, Ayam SenSi, Ayam Gaok, Ransum

\section{ABSTRACT}

Hidayat C, Iskandar S, Sartika T, Wardhani T. 2016. Growth response of improved native breeds of chicken to diets differed in energy and protein content. JITV 21(3): 174-181. DOI: http://dx.doi.org/10.14334/jitv.v21i3.1397

The aim of doing this experiment was to observe the growth response of improved native breeds of chicken under diets differed in energy and protein content. Three groups of improved native breeds, obtained from mating of $\jmath^{\lambda} \mathrm{KUB}$ to 을 (Line

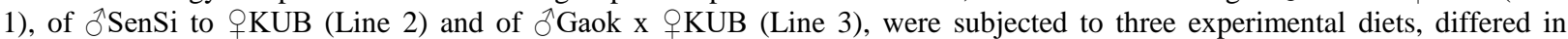
metabolizable energy (ME) and crude protein (CP) content. The experimental diets consisted of Diet $1(2,800 \mathrm{kcal} \mathrm{ME} / \mathrm{kg}$ with $17,81 \% \mathrm{CP})$, Diet 2 (2,950 kcal ME/ kg with 18,61\% CP) and Diet 3 (3,100 kcal ME/ kg with 19,25\% CP). The experiment was designed as factorial $3 \times 3$ with 7 replications of each treatment combination, consisted of 5 birds per treatment combination. The chickens were raised up to 10 weeks of age. Results of the experiment showed that Line 2 ( $\delta$ SenSi mated to ${ }_{1} \mathrm{KUB}$ ) had highest body weight at 10 weeks of age $(\mathrm{P}<0.05)$, lowest feed conversion ratio $(\mathrm{FCR})$ and highest European Production Efficiency Factor (EPEF), compared to other two lines. The appropriate diet for Line 2 was Diet 2. It could be concluded the crossbred line that was resulted from crossing of $\lesssim$ SenSi to $\$$ KUB (Line 2), had potential to be used as improved native chicken for the industry in Indonesia supported by appropriate diet containing 2,950 kcal ME/kg with $18.61 \%$ crude protein.

Key Words: KUB Chicken, SenSi Chicken, Gaok Chicken, Diets

\section{INTRODUCTION}

The increase in demands of native chicken meat in the last decade in Indonesia has been followed by the finding of native KUB chicken as moderately improved native chicken breed. The KUB chicken was selected for egg production subjected to be female line in supporting the production of native day old chick (DOC) for national meat production (Iskandar \& Sartika 2014; Hidayat et al. 2011; Hidayat et al. 2014). To create KUB as female line, the IRIAP (Indonesian
Research Institute for Animal Production) has also produced SenSi-chicken (Iskandar et al. 2012; Hidayat et al. 2014) and Gaok-chicken (Sartika et al. 2007) as the candidate of male lines in the IRIAP's research project to create grand parent or parent stocks of improved meat type of native chicken.

In order to have an optimum performance as an expression of genetically improved breed, the appropriate supports, such as optimum and appropriate feeding management, including nutrient requirements, is needed to increase biological and economic 
efficiency. As strongly stated by Leeson (2011), the changing in commercial goals impinge on nutrient needs and feeding programs. Applegate \& Angel (2014) reported that scientific community has begun to embrace the concept of return on investment of nutrient used for compositional growth or egg production. The concept has inspired our experiment to find out the optimum level of dietary energy and protein for new improved breeds of native chicken (KUB, SenSi, and Gaok chickens).

Therefore this experiment was aimed to observe the growth response of improved breeds of native chicken raised with rations differed in dietary energy and protein content.

\section{MATERIALS AND METHODS}

\section{Experimental animal}

Three hundred and fifteen day old chickens (DOC) of improved native breeds obtained from mating of

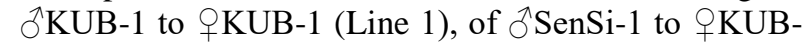
1 (Line 2) and of $\$$ Gaok to $+\mathrm{KUB}-1$ (Line 3), were subjected to three experimental rations, differed in dietary ME and dietary $\mathrm{CP}$ contents. Each treatment combination was replicated by seven and the experimental design used was randomized complete design in factorial arrangement $3 \times 3$. In each treatment combination there were five unsexed-DOCs, randomly picked and confined in a colony wire cage with floor space of $35 \mathrm{~cm}$ x $35 \mathrm{~cm}$ and height of $40 \mathrm{~cm}$. Heating light bulb was constructed to provide proper heat during brooding age. Feed in mash form and drinking water were provided ad libitum.

Health programs such as vaccination with proper vaccines and cage sanitation were also applied following the health and sanitations programs for modern broiler, up to ten weeks of age. Immunization program consisted of: i) At four days old the DOC were vaccinated against NDIB (new castle disease and infectious bronchitis); ii) At seven days old the chickens were vaccinated against IBD (gumboro); iii) The IBD vaccine was repeated in day 21 ; iv) Newcastle disease vaccine was repeated at the age of 28 days. There was no more vaccination applied afterward until the experiment was ended when the chicks were 10 weeks of age.

Table 1. Experimental diets given to the unsexed improved breeds of native chicken up to 10 weeks of age

\begin{tabular}{|c|c|c|c|}
\hline Ingredients & Diet $1^{3)}$ & Diet 2 & Diet 3 \\
\hline Fish meal, (\%) & 5.00 & 5.00 & 7.83 \\
\hline Corn, $(\%)$ & 44.65 & 41.16 & 57.15 \\
\hline Soybean meal, $(\%)$ & 16.07 & 18.66 & 19.61 \\
\hline Rice bran, $(\%)$ & 30.00 & 30.00 & 10.00 \\
\hline Vegetable oil, (\%) & 1.00 & 2.17 & 3.00 \\
\hline $\mathrm{CaCO} 3,(\%)$ & 1.51 & 1.19 & 0.99 \\
\hline Dicalcium Phosphate, (\%) & 0.68 & 0.67 & 0.39 \\
\hline $\mathrm{NaCl},(\%)$ & 0.25 & 0.25 & 0.20 \\
\hline $\operatorname{Top~Mix~}^{1)},(\%)$ & 0.30 & 0.30 & 0.30 \\
\hline L-Lysine, (\%) & 0.17 & 0.19 & 0.13 \\
\hline DL-Methionine, $(\%)$ & 0.17 & 0.21 & 0.20 \\
\hline Chlorin Cloride, $(\%)$ & 0.10 & 0.10 & 0.10 \\
\hline Sodium bicarbonate, $(\%)$ & 0.10 & 0.10 & 0.10 \\
\hline Total, $(\%)$ & 100 & 100 & 100 \\
\hline \multicolumn{4}{|l|}{ Nutrient content: } \\
\hline Crude protein, $(\%)$ & 17.81 & 18.61 & 19.25 \\
\hline Energy, $\left(\mathrm{kcal} \mathrm{ME}^{2)} / \mathrm{kg}\right)$ & 2800 & 2950 & 3100 \\
\hline Energy/protein ratio, (kcal ME/kg protein) & 15.72 & 15.85 & 16.10 \\
\hline Calcium, $(\%)$ & 1.31 & 1.12 & 1.24 \\
\hline Total phosphorous, (\%) & 0.72 & 0.89 & 0.62 \\
\hline Calcium/Phosphorus ratio & 1.82 & 1.26 & 2.00 \\
\hline Lysine, $(\%)$ & 0.36 & 0.36 & 0.38 \\
\hline Methionine, $(\%)$ & 0.19 & 0.16 & 0.17 \\
\hline Crude fiber, $(\%)$ & 4.99 & 5.13 & 4.42 \\
\hline
\end{tabular}


efficient breeding program in order to produce final lines for improved meat type of native chicken.

In the purpose of improving performance of Indonesian native chicken, although it does not have a high body weight especially at early age like modern broiler, the native chicken is the breed with tolerance to hot and humid climate. Attempts of breeding the birds with tolerance breed to specific nutritional deficiencies as indicated by Pym (2011) may considerably be overcome by the use of available commercial feed ingredients and complete feed for modern chicken industry.

Live weight at 10 weeks of age was influenced by nutrition as shown in Table 2. Diet 2 containing 2,961 $\mathrm{kcal} \mathrm{ME} / \mathrm{kg}$ with $18.61 \%$ crude protein, offered better feed to chicks with the highest $(\mathrm{P}<0.05)$ live weight (840 g/bird) compared to Diet 1 (771 g/bird or Diet 3 $(720 \mathrm{~g} / \mathrm{bird})$. Lowest $(\mathrm{P}<0.05)$ live weight of the chicken in Diet 3, containing 3,100 kcal ME/kg with $19.25 \%$ crude protein, showing that this diet was not much suitable for the chicken. The dietary energy of Diet 3, somehow may probably increase in order to balance the appropriate ratio, however, Diet 2 with lower crude protein and energy would be more efficient.

\section{Feed consumption and efficiency}

There was no effect of interaction of breed and nutrition $(\mathrm{P}>0.05)$ on feed consumption. Line 3 ( $\delta \mathrm{Gaok}$ $\mathrm{x}$ ○KUB-1) consumed less feed $(2,341 \mathrm{~g} / \mathrm{bird} ; \mathrm{P}<0.05)$ compared to the other two breeds $(2,502 \mathrm{~g} / \mathrm{bird}$ for Line 2 and 2,517 g/bird for Line 1) (Table 2). It seemed that improving performance of native chicken decreased feed consumption as it was shown by the early selected Sentul chicken, which is the grand parent of SenSi chicken, consumed the same quality feed more $(2,602$ $\mathrm{g} / \mathrm{bird}$ ) at the same age (Iskandar et al. 2012), however, it was slightly more when compared to SenSi chicken fed with different quality of ration $(2,400 \mathrm{~g} / \mathrm{bird}$, Iskandar et al. 2015).

There was significant effect $(\mathrm{P}<0.05)$ of interaction between breeds and quality of experimental rations on feed conversion ratio (FCR). Table 3 show that chicken in ration Diet 2 significantly $(\mathrm{P}<0.05)$ had the best FCR than the other two experimental diets. Feed formulation of Diet 2, containing 2,950 kcal ME/kg with $18.61 \%$ crude protein was probably the optimum for all lines. Line 2 ( $₫$ SenSi-1 x $q$ KUB) feed utilization was more efficient than the Line 1 or Line 3, although the value of feed conversion ratio slightly higher $(3.09 \mathrm{~kg} / \mathrm{kg})$ than that of reported by Iskandar et al. (2015) of about 2.5 $\mathrm{kg} / \mathrm{kg}$. In term of FCR Line 2 converted feed more efficiently into body on Diet 1 , which contained 2800 $\mathrm{kcal} \mathrm{ME} / \mathrm{kg}$ with $17.81 \% \mathrm{CP}$, while the other two lines were on Diet 2 . Chicken of the Line 1 would actually be expected to consume more feed to grow a kilo gram of its live weight than other lines, as it was selected for egg production.

Economic efficiency in term of EPEF (European Production Efficiency Factor) suggested by Marcu et al. (2013) was also used to measure the economic efficiency. There was significant $(\mathrm{P}<0.05)$ effect of interaction between lines and diets. Table 3 shows inverse pattern of FCR and confirms that line S2 chicken was more efficient than that of other two lines fed diet Diet 2. The highest value (EPEF of 411) was achieved by Line 2 ( $\lesssim$ SenSi-1 x $९$ KUB) on diet Diet 2, while the lowest (EPEF of 296) was achieved by Line 1 on Diet 3. So, in term of EPEF young chicks of crossbred of ${ }^{1}$ SenSi-1 x 9 KUB-1 (Line 2) would perform much better on Diet 2 .

\section{Mortality}

Mortality values were presented in Table 2, there was not any significant $(\mathrm{P}>0.05)$ difference between

Tabel 3. Feed Conversion Ratio (FCR), European Production Efficiency Factor (EPEF) of unsexed improved breeds of native chicken given experimental diets up to 10 weeks of age

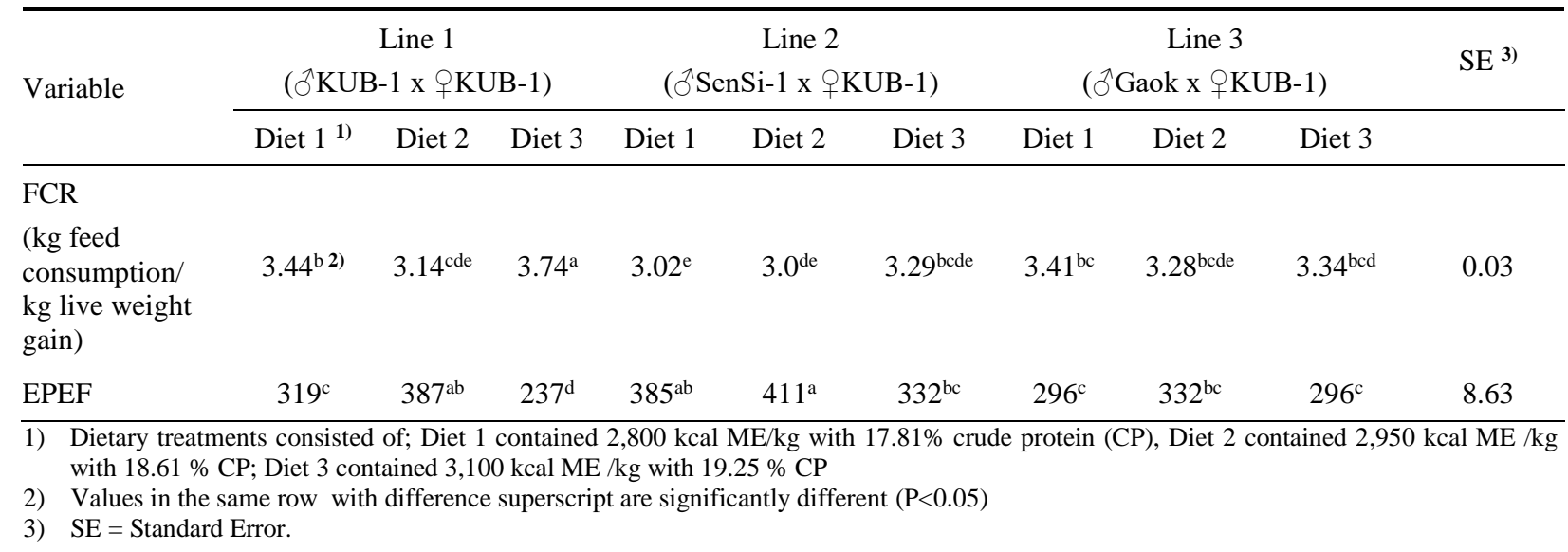


experimental factor either breeds factor nor diets factor. It could not be concluded as it had higher standard error of mean. The high mortality of $4.76 \%$ happened in Line 1 compared to $0.95 \%$ in line Line 2. There was no satisfactory explanation why such mortality figures appeared in the experiment.

\section{Nutrients consumed}

Nutrients consumption in term of $\mathrm{g} / \mathrm{kg}$ body live weight (BLW) was presented in Table 4 . The nutrients consumption was affected by the interaction $(\mathrm{P}<0.05)$ of breeds and diets. Therefore, the figures show that each breed of chicken should have its own optimum level, depended on the genetic capacity.

Dietary ME (metabolizable energy) consumed by the birds, varied with breeds and diet factors. Dietary ME was utilized efficiently to a kilo gram $(\mathrm{kg})$ of BLW was by crossbred ${ }^{\lambda}$ SenSi-1 x 'KUB-1 on Diet $1(8,150$ kcal ME/kg BLW), meanwhile ఫ̄Gaok $\mathrm{x}$ ○ KUB-1 $(9,147 \mathrm{kcal} / \mathrm{kg} \mathrm{BLW})$ was on Diet 1 , which was not significantly $(\mathrm{P}>0.05)$ from the other two lines on the same diet. The figures, which are the amount of energy consumed per $\mathrm{kg}$ BLW, could be interpreted as efficiency of particular nutrient in part of formation one $\mathrm{kg}$ BLW of chicken. The lower dietary energy consumed, the more efficient the bird in utilizing diet.

From point of genetic capacity, all lines did not show response of increasing consumption of dietary energy when fed low energy diet. It is unlike the old concept which stated that bird will consumed more diet on low energy density diet. This phenomenon was also discussed by Mbajiorgu et al. (2011) on native Venda chicken, due to the loss sensitivity to regulate feed intake according to dietary energy level, although the physiological explanation was not clear and merited further investigation.

The pattern of crude protein and lysine consumptions $(\mathrm{g} / \mathrm{kg} \mathrm{LW})$ followed pattern of their energy consumption (Table 4), leading to indication that crossbred ${ }^{\top}$ SenSi-1 x TKUB-1 chicken was more efficient in utilizing protein and amino acid lysine in Diet 1, whilst all breeds utilized dietary protein and energy of Diet 2 was fairly similar. Diet 3 was not quite appropriate in having energy, protein and lysine levels available for supporting the maximum growth of the three breeds. As a result of that occurs in Diet 3 allegedly associated with an imbalance of nutrients that occurs on Diet 3. Dairo et al. (2010) revealed that increase of energy content of the experimental diets indicated to a large extent adequacy of supply of other nutrients even at the minimal dietary level, hence formulation of animal feed must take into consideration the nutrient density with energy as the prime factor of the particular feed to facilitate production objectives.

Methionine and calcium consumptions were having much the same pattern, showing that all lines utilized amino acid methionine and calcium more efficient on Diet 2 in comparison to the other two experimental diets. However, contrary to the response of lines to those two nutrients, phosphorus consumption was more on Diet 2 compared to other two diets. This case is likely due to the ratio of $\mathrm{Ca} / \mathrm{P}$ are different ratio of $\mathrm{Ca} / \mathrm{P}$ in all three treatment diets and not ideal for chicken since the ideal ratio of $\mathrm{Ca} / \mathrm{P}$ is $3: 1$.

Table 4. Nutrients consumed of unsexed improve breeds of native chickens given experimental rations up to 10 weeks of age

\begin{tabular}{|c|c|c|c|c|c|c|c|c|c|c|}
\hline \multirow[t]{2}{*}{ Consumption } & \multicolumn{3}{|c|}{$\begin{array}{c}\text { Line } 1 \\
\left({ }^{\top} \text { KUB-1 x } 9 \text { KUB-1) }\right. \\
\end{array}$} & \multicolumn{3}{|c|}{$\begin{array}{c}\text { Line } 2 \\
(\lesssim \text { SenSi-1 x } 9 \text { KUB-1) } \\
\end{array}$} & \multicolumn{3}{|c|}{$\begin{array}{c}\text { Line } 3 \\
\left({ }^{\lambda} \text { Gaok x } 9 \text { KUB-1) }\right. \\
\end{array}$} & \multirow[t]{2}{*}{ SEM ${ }^{5)}$} \\
\hline & Diet $1^{3 \text { ) }}$ & Diet 2 & Diet 3 & Diet 1 & Diet 2 & Diet 3 & Diet 1 & Diet 2 & Diet 3 & \\
\hline $\begin{array}{l}\text { Energy, } \\
(\mathrm{kcal} \mathrm{ME} \mathrm{1)/} \mathrm{kg} \\
\left.\mathrm{BLW}^{2)}\right)\end{array}$ & $9,251^{\text {bc } 4)}$ & $8,931^{\mathrm{c}}$ & $11,073^{\mathrm{a}}$ & $8,150^{\mathrm{d} 4)}$ & $8,818^{\mathrm{cd}}$ & $9,796^{\mathrm{b}}$ & $9,147^{b c}$ & $9,295^{\mathrm{bc}}$ & $9,910^{\mathrm{b}}$ & 125 \\
\hline $\begin{array}{l}\text { Crude Protein, } \\
\text { (g/kg BLW) }\end{array}$ & $588^{\text {bcd }}$ & $563^{\text {cde }}$ & $687^{\mathrm{a}}$ & $518^{\mathrm{e}}$ & $556^{\mathrm{de}}$ & $608^{\mathrm{bc}}$ & $581^{\text {bcd }}$ & $586^{\mathrm{bcd}}$ & $615^{\mathrm{b}}$ & 7.41 \\
\hline $\begin{array}{l}\text { Lysine, } \\
\text { (g/Kg BLW) }\end{array}$ & $11.89^{\mathrm{b}}$ & $10.90^{\mathrm{cd}}$ & $13.57^{\mathrm{a}}$ & $10.48^{\mathrm{d}}$ & $10.76^{\mathrm{d}}$ & $12.01^{\mathrm{b}}$ & $11.76^{\mathrm{bc}}$ & $11.34^{\mathrm{bcd}}$ & $12.14^{\mathrm{b}}$ & 0.14 \\
\hline $\begin{array}{l}\text { Methionine, } \\
\text { (g/kg BLW) }\end{array}$ & $6.27^{\mathrm{a}}$ & $4.84^{\mathrm{d}}$ & $6.07^{\mathrm{a}}$ & $5.53^{\mathrm{b}}$ & $4.78^{\mathrm{b}}$ & $5.37^{\mathrm{bc}}$ & $6.20^{\mathrm{a}}$ & $5.04^{\mathrm{cd}}$ & $5.43^{\mathrm{bc}}$ & 0.08 \\
\hline $\begin{array}{l}\text { Calcium, } \\
(\mathrm{g} / \mathrm{kg} \mathrm{BLW})\end{array}$ & $43.28^{\mathrm{a}}$ & $33.90^{\mathrm{d}}$ & $44.29^{\mathrm{a}}$ & $38.13^{\mathrm{bc}}$ & $33.48^{\mathrm{d}}$ & $39.18^{\mathrm{b}}$ & $42.79^{\mathrm{a}}$ & $35.29^{\mathrm{cd}}$ & $39.64^{b}$ & 0.58 \\
\hline $\begin{array}{l}\text { Phosphorus, } \\
\text { (g/kg BLW) }\end{array}$ & $23.78^{b}$ & $26.94^{\mathrm{a}}$ & $22.14^{\mathrm{bc}}$ & $20.95^{\mathrm{cd}}$ & $26.60^{\mathrm{a}}$ & $19.59^{\mathrm{d}}$ & $23.52^{\mathrm{b}}$ & $28.04^{\mathrm{a}}$ & $19.82^{\mathrm{d}}$ & 0.41 \\
\hline \\
\hline \multicolumn{11}{|c|}{$\begin{array}{l}\text { 1) ME : Metabolizable Energy } \\
\text { 2) BLW : Body Live Weight }\end{array}$} \\
\hline \multicolumn{11}{|c|}{$\begin{array}{l}\text { 3) Dietary treatments consisted of; Diet } 1 \text { contained } 2,800 \mathrm{kcal} \mathrm{ME} / \mathrm{kg} \text { with } 17.81 \% \text { crude protein }(\mathrm{CP}) \text {, Diet } 2 \text { contained } 2,950 \mathrm{kcal} \mathrm{ME} / \mathrm{kg} \\
\text { with } 18.61 \% \text { CP. Diet } 3 \text { contained } 3.100 \mathrm{kcal} \mathrm{ME} / \mathrm{kg} \text { with } 19.25 \% \mathrm{CP}\end{array}$} \\
\hline \multicolumn{11}{|c|}{ 4) Values in the same row with different superscript are significantly different $(\mathrm{P}<0.05)$} \\
\hline 5) $\mathrm{SE}$ & rror of $\mathrm{M}$ & & & & & & & & & \\
\hline
\end{tabular}


The phenomenon also mentioned by Mbajiorgu et al. (2011) in their discussion paper that chickens will increase intake in response to marginal level of first limiting feed nutrient and independent of dietary energy level (Boorman 1979) since appetite was assumed to depend on nutrient requirements of the animal and the contents of those nutrients in the feed (Emmans \& Fisher 1986). However, contrary to the fact that phosphorus level in Diet 2 was higher than that level in Diet 1 or Diet 3. The increase in feed consumption was not clearly due to phosphorus level in the diet. Adamu et al. (2012) reported that dietary $\mathrm{Ca}: \mathrm{P}$ ratio of $3: 1$ was favorable for finishing broiler chickens under semiarid environment. In this experiment $\mathrm{Ca}: \mathrm{P}$ ratios were 1.86, 1.26 and 2.00 respectively for Diet 1, Diet 2 and Diet 3, which might not at proper ratios. The finding suggested us to do further investigation, particularly with native chickens.

\section{Carcass}

Carcass in term of dressing percentage and carcass cuts are presented in Table 5. There was no significant (P>0.05) effect of the interaction between breeds and quality of experimental diets on carcass. The data were analyzed according to each factor. Line 1 chicken had slightly higher $(\mathrm{P}<0.05)$ dressing percentage $(64.94 \%)$ compared to the other two breeds performing only up to about $63 \%$ dressing percentage. There were no significant $(\mathrm{P}>0.05)$ different in breast, gizzard and fat pad percentage among the three breeds. Slightly higher thighs percentage $(10.58 \%)$ and liver percentage $(2.43 \%)$ of Line 1 chicken revealed in the experiment. The carcass performance of the all lines of the chicken for some extent was not much different from other Indonesian native chicken as reported by Iskandar et al. (2012) on Sentul native chicken of having dressing percentage of $62 \%$ for female and $71 \%$ for male, and of having breast percentage of about $17 \%$ for both female and male at 10 week of age. There was obviously, lower than dressing breast, thighs percentage of exotic broiler chickens (Beg et al. 2016).

However, it is interesting to note in native that the abdominal fat pad was much lower, showing that the native chicken meat would be much healthier than exotic broiler chicken for human consumption (Ewald 2015). Furthermore, Guan et al. (2013) reported that native chickens produced better quality meat as far as inosine-5' monophosphate (IMP) content, fiber diameter, and shear forces were concerned.

Table 5. Percentage of dressing, breast, thighs, drumstick, liver, gizzard, abdominal fat pad of 10 weeks old of unsexed improved breeds of native chicken given diets differed in nutrients content.

\begin{tabular}{|c|c|c|c|c|c|c|c|}
\hline Factors & $\begin{array}{c}\text { Dressing } \\
(\%)^{3)}\end{array}$ & $\begin{array}{c}\text { Breast } \\
(\%)\end{array}$ & $\begin{array}{c}\text { Thighs } \\
(\%)^{1)}\end{array}$ & $\begin{array}{c}\text { Drumstick } \\
(\%)\end{array}$ & $\begin{array}{c}\text { Liver } \\
(\%)\end{array}$ & $\begin{array}{c}\text { Gizzard } \\
(\%)\end{array}$ & $\begin{array}{l}\text { Abdominal } \\
\text { fat pad } \\
(\%)\end{array}$ \\
\hline \multicolumn{8}{|l|}{ Lines (L) } \\
\hline Line 1 (ðKUB-1 x $甲$ KUB-1) & $63.00^{\mathrm{b} 4)}$ & $16.06^{\mathrm{a}}$ & $11.06^{\mathrm{b} 2)}$ & $10.19^{b}$ & $2.38^{\mathrm{b}}$ & $2.62^{\mathrm{a}}$ & $0.52^{\mathrm{a}}$ \\
\hline Line $2(\widehat{\partial}$ SenSi-1 $x$ 吕UB-1) & $63.18^{\mathrm{b}}$ & $15.44^{\mathrm{a}}$ & $11.34^{\mathrm{ab}}$ & $10.49^{\mathrm{a}}$ & $2.56^{\mathrm{a}}$ & $3.72^{\mathrm{a}}$ & $0.42^{\mathrm{a}}$ \\
\hline Line 3 ( $\widehat{o}$ Gaok x $甲$ KUB-1) & $64.94^{\mathrm{a}}$ & $16.06^{\mathrm{a}}$ & $11.58^{\mathrm{a}}$ & $10.42^{\mathrm{ab}}$ & $2.43^{\mathrm{ab}}$ & $2.85^{\mathrm{a}}$ & $0.17^{\mathrm{a}}$ \\
\hline $\mathrm{SE}^{1)}$ & 0,86 & 0,39 & 0,25 & 0,16 & 0,09 & 0,50 & 0,22 \\
\hline \multicolumn{8}{|l|}{ Diets (D) } \\
\hline Diet $1^{2)}$ & $63.93^{x}$ & $15.59^{y}$ & $11.47^{x}$ & $10.40^{\mathrm{x}}$ & $2.45^{\mathrm{xy}}$ & $2.85^{\mathrm{x}}$ & $0.24^{\mathrm{x}}$ \\
\hline Diet 2 & $64.07^{x}$ & $16.26^{\mathrm{x}}$ & $11.27^{\mathrm{x}}$ & $10.23^{\mathrm{x}}$ & $2.36^{\mathrm{y}}$ & $2.86^{\mathrm{x}}$ & $0.38^{x}$ \\
\hline Diet 3 & $63.12^{\mathrm{y}}$ & $15.71^{x y}$ & $11.24^{\mathrm{x}}$ & $10.47^{\mathrm{x}}$ & $2.56^{\mathrm{x}}$ & $3.48^{\mathrm{x}}$ & $0.48^{\mathrm{x}}$ \\
\hline SE & 0.92 & 0.39 & 0.26 & 0.17 & 0.09 & 0.52 & 0.23 \\
\hline \multicolumn{8}{|l|}{ Interaction } \\
\hline$L \times D$ & NS $\mathbf{5})$ & NS & $\mathrm{NS}^{5)}$ & NS & NS & NS & NS \\
\hline \multicolumn{8}{|l|}{ 1) $\mathrm{SE}=$ Standard Error } \\
\hline $\begin{array}{l}\text { 2) Dietary treatments consisted of; } \\
\text { with } 18.61 \% \mathrm{CP} \text {; Diet } 3 \text { contain } \\
\text { 3) As the ratio to live weight } \\
\text { 4) Values in the same column and } f \\
\text { 5) NS = Not Significant }(P>0.05) \text {. }\end{array}$ & $\begin{array}{l}\text { contained } 2 \\
\text { kcal ME /k } \\
\text { ith differenc }\end{array}$ & $\begin{array}{l}00 \mathrm{kcal} \mathrm{M \digamma} \\
\text { with } 19.25 \\
\text { uperscript }\end{array}$ & $\begin{array}{l}\mathrm{g} \text { with } 17 \\
\mathrm{CP} \\
\text { e significa }\end{array}$ & ly different $(\mathrm{P}$ & $\begin{array}{l}\mathrm{n}(\mathrm{CP}) \text {, } \\
.05)\end{array}$ & $2 \mathrm{cont}$ & $2,950 \mathrm{kcal} \mathrm{N}$ \\
\hline
\end{tabular}


The influence of experimental diets on carcass percentage was statistically significant $(\mathrm{P}<0.05)$, showing that Diet 2 facilitated better to produce more dressing, and breast percentage. Whilst the other carcass cuts, except liver, were not influenced by the level of dietary energy and protein. Abdominal fat pad varied from $0.24 \%$ to $0.48 \%$ with varying in protein or energy content of the diets. The gap of figures was actually wide, but it was not any statistically different. This was due to the high SEM $(0.23 \%)$ as the result of high variation of the individual bird fat pad and constant energy/protein ratio (about $158 \mathrm{kcal} \mathrm{ME} / \mathrm{kg}$ crude protein). However, the level of fat pad of the native chicken breeds was again much lower than of exotic broiler chicken (Azizi et al. 2011). The absence of effect on dressing percentage and cut carcass composition associated with the similar protein energy ratio among all treatment diets, Rosa et al. (2007) said that some of the results of the experiment showed that the content of energy and protein in the diet had no influence on the composition of cut carcass composition of chicken.

\section{CONCLUSION}

It is concluded that Line 1 ( $\mathrm{O}$ KUB- $1 \mathrm{x}$ ○ KUB-1) and its crossbreeds, Line 2 ( $\overbrace{\text { SenSi-1 }}$ x $q$ KUB-1) and

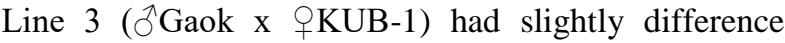
biological response to rations differ in nutrient content. Meanwhile, indigenous crosses breed ${ }^{\top}$ SenSi-1 $x$ qKUB-1 potential for commercial native meat chicken in Indonesia with diet contained 2,950 kcal ME/kg with $18.61 \%$ crude protein raised up to 10 weeks of age.

\section{REFERENCES}

Adamu SB, Geidam YA, Mohammed G, Gambo HI, Raji AO. 2012. The influence of varying calcium-phosphorus ratios on finishing and carcass characteristics of broiler finisher chickens under a semi arid environment. ARPN J Agric Biol Sci. 7:558-563.

Ali SAM, Hyder O. Abdalla, Mahgoub IM. 2011. Effect of slaughtering method on the keeping quality of broiler chickens' meat. Egypt Poult Sci. 31:727-736.

Applegate TJ, Angel R. 2014. Nutrient requirements of poultry publication: History and need for an update. J Appl Poult Res. 23:1-9 doi: dx.doi.org/10.3382/japr. 2014-00980.

Azizi B, Sadeghi G, Karimi A, Abed F. 2011. Effects of dietary energy and protein dilution and time of feed replacement from starter to grower on broiler chickens performance. J Central Eur Agric. 12:44-52.

Beg MAH, Saiful Islam KBM, ftabuzzaman MA, Mahbub ASM. 2016. Effects of separate sex growing on performance and metabolic disorders of broilers. Int $\mathrm{J}$ Anim Resourc. 1:19-26.
Boorman KN. 1979. In: Food Intake Regulation in Poultry, pp: 87-126. Boorman KN, Freeman BM, Editors. Edinburgh.

Dairo FAS, Adesehinwa AOK, Oluwasola TA, Oluyemi JA. 2010. High and low dietary energy and protein levels for broiler chickens. Afr J Agric Res. 5:2030-2038. doi: 10.5897/AJAR10.254.

Emmans GC, Fisher C. 1986. Problems in nutritional theory. In: Nutrient Requirements of Poultry and Nutritional Research. Fisher C, Boorman KN, editors. Oxford, Butterworths (UK): National Research Council. p. 9-39.

Ewald J. 2015. Chicken Big: Poultry and Obesity | NutritionFacts.org." Accessed January 31, 2017. http://lifeandhealth.org/nutrition/chicken-and-obesity/ 093184.html.

Guan RF, Lyu F, Chen XQ, Ma JQ, Jiang H, Xiao CG. 2013. Meat quality traits of four Chinese native chicken breeds and one commercial broiler stock. J Zhejiang Univ Sci B. 14:896-902.

Hafiz AO, Hassan Z, Manap MNA. 2015. Effect of slaughtering methods on meat quality indicators, chemical changes and microbiological quality of broiler chicken meat during refrigerated storage. IOSR J Agric Vet Sci. 8:12-17. doi: 10.9790/2380-08911217.

Hidayat C, Iskandar S, Sartika T. 2011. Response of laying performance of KUB chicken to dietary protein given during growing period. JITV. 16:83-89.

Hidayat C, Sumiati, Iskandar S. 2014. Growth responses of native chicken Sentul G-3 on diet containing high ricebran supplemented with phytase enzyme and $\mathrm{ZnO}$. JITV. 19:193-202. doi: dx.doi.org/10.14334/jitv.v19i3. 1082

Iskandar S, Gunawan B, Resnawati H. 2012. Initiation of selection in Sentul native chicken: Ten weeks growth rate. Wina E, Prasetyo LH, Inounu I, Priyanti A, Anggraeni A, Yulistiani D, Sinurat AP, Situmorang P, Wardhana AH, Dharmayanti NLPI, et al., editors. Proceeding International Conference on Livestock Production and Veterinary Technology. Bogor (Indones): Indonesian Center for Animal Research and Development. p. 35-39.

Iskandar S, Hidayat C, Cahyaningsih T. 2015. Growth efficiency of meat-type native SenSi chicken fed prestarter diet during the first 24 hours. Noor SM, Handiwirawan E, Martindah E, Widiastuti R, Sianturi RSG, Herawati T, Purba M, Anggraeni YN, Batubara A, editors. Prosiding Seminar Nasional Teknologi Peternakan dan Veteriner. Bogor (Indones): Pusat Penelitian dan Pengembangan Peternakan. p. 460-466

Iskandar S, Sartika T, Hidayat C, Kadiran. 2011. Performance response of the selected kampung chicken to dietary protein. Indones J Nutr Feed Sci. 2:73-79.

Iskandar S, Sartika T. 2014. KUB chicken: "The first Indonesian kampung chicken selected for egg production”. Subandriyo, Kusmartono, Santosa KA, Kurnianto E, Purnomoadi A, Sodiq A, Wiryawan KG, 
Darodjah S, Inounu I, Darmono, Priyanti A, Wynn P, Han JL, Tay-Hsu J, Idrus Z, editors. Proceedings the 16th AAAP Congress. Yogyakarta (Indones): Gadjah Mada University. p. 157-160.

Leeson S. 2010. Nutrition and healty: Poultry. Feedstuffs. 14 September edition. p. 52-60.

Marcu A, Vacaru-Opri I, Dumitrescu G, Petculescu-Ciochina L, Marcu A, Nicula M, Pet I, Dronca D, Kelciov B, Maris C. 2013. The influence of genetics on economic efficiency of broiler chickens growth. Anim Sci Biotechnol. 46:339-346.

Mbajiorgu CA, Ng'ambi JW, Norris DD. 2011. Voluntary feed intake and nutrient composition in chickens. Asian J Anim Vet Adv. 6:20-28. doi: 10.3923/ajava.2011. 20.28 .

[NRC] National Research Council. 1994. Nutrient Requirement for poultry. USA: National Research Council, National Academic Sciences.

Pym R. 2011. Poultry genetics and breeding in developing countries: Genetic approaches to improved performance in sub-optimal conditions. USA: Food and Agriculture Organization of the United Nations, Poultry Development Review. p. 1-3.

Rosa PS, Faria-Filho DE, Dahlke F, Vieira BS, Macari M, Furlan RL. 2007. Effect of energy intake on performance and carcass composition of broiler chickens from two different genetic groups. Braz J Poult Sci.9:117-122.

Sartika T, Sulandari S, Zein MSA, Paryanti S. 2007. Mengangkat potensi genetik dan produktivitas ayam gaok. Diwyanto K, Subandriyo, Handiwirawan E, Agustina L, Kurniawaty ET, editors. Prosiding Lokakarya Nasional Pengelolaan dan Perlindungan Sumber Daya Genetik di Indonesia. Bogor (Indones): Pusat Penelitian dan Pengembangan Peternakan. p. 251256.

Tavárez MA, Solis de los Santos F. 2016. Impact of genetics and lineing on broiler production performance: a look into the past, present, and future of the industry. Anim Frontiers. 6:37-41. doi: 10.2527/af.2016-0042. 